He then goes on to say: "It is worth adding that, not very far from the Rotorua district, in the now famous gold-fields of the Thames, an eminent but dogmatic and hasty geologist many years ago prophesied that no gold could there ever be found." As the Thames gold-fields were well established fifteen years or more before Professor Posnett came to Auckland, this charge must rest on secondor third-hand evidence; for, to the best of my knowledge, the prophecy was never published. As I was living in Auckland at the time of the discovery of the fields (1867), I should certainly have heard of it if any scientific man had said publicly that no gold would be found at the Thames. When Professor Posnett was in Auckland he could easily have investigated the truth of club gossip, and he should have done so before repeating it as a well-attested fact. I therefore call upon him either to produce his evidence or to acknowledge that he has done the very thing he is blaming geologists for doing, namely, made dogmatic statements without giving any hint that they may not be true.

F. W. Hurron.

Christchurch, New Zealand.

31 st August, 1900.

\title{
THE AGE OF THE RAISED BEACH OF SOUTHERN BRITAIN.
}

SIR,-Mr. Tiddeman's extremely interesting note in the October. Number "On the Age of the Raised Beach as seen at Gower" seems. to be supported by several facts, which I had observed and already published with regard to the Raised Beach in Sussex. The section to the west of Brighton exhibits, near the top, a distinctly festooned arrangement of the lines of bedding, which can be best explained on the supposition of the occurrence of interbedded ice-masses. ${ }^{\mathrm{I}}$ Another important point is the discovery of two species of Ostracoda. of northern habit in the Sussex Raised Beach. ${ }^{2}$ And further, the Rubble-Drift immediately above the Raised Beach at Aldrington shows decided evidence of a continuation of a rigorous climate, for here there are some blocks of almost pure foraminiferal sand, very friable, but with their own wavy bedding preserved, which leads one to conclude that these fragments were transported in a frozen condition. ${ }^{3}$ I may also, perhaps, be allowed to draw attention to the excellent sections of the Raised Beach and Rubble-Drift which can now be visited at Copperas Gap, near Portslade-by-Sea, but which is being rapidly cut away by the work of sand excavation.

111, OAKHILL ROAD,

Frederiok Chapian, A.L.S. Putiey, S.W.

1 Transactions of the Union of South-Eastern Scientific Societies, 1900, p. 58.

2 Proc. Geol. Assoc., vol. xvi, pt. 6, p. 263.

3 Ibid., pp. 267, 268. 